\title{
UTAUT: Analysis of Usage Level of Android Applications as Learning Media in Indonesian Educational Institutions
}

\author{
Vera Mandailina ${ }^{1}$, Saddam ${ }^{2}$, Malik Ibrahim ${ }^{3}$, Syaharuddin ${ }^{4}$ \\ ${ }^{1,2,4}$ Universitas Muhammadiyah Mataram, Indonesia \\ ${ }^{3}$ Universitas Nahdlatul Ulama NTB, Indonesia \\ ㅁvrmandailina@gmail.com, ${ }^{2}$ saddamalbimawi1@gmail.com, ${ }^{3}$ malikedu.org@gmail.com, \\ syaharuddin.ntb@gmail.com,
}

\begin{abstract}
ABSTRAK
Keyword:

UTAUT;

Android Application;

Instructional Media.

This study aims to analyze the application of android applications as a medium of mathematics learning in Indonesian educational institutions using the Unified Theory of Acceptance and Use of Technology (UTAUT) method both among teachers in delivering mathematical material and students in experimenting or completing school assignments. The research method used was descriptive quantitative with a four option Likert Scale questionnaire as a research instrument. Surveys were deployed using the Google Form-based Black Box system throughout Indonesia through Social Media. Based on the results of data analysis obtained information that the application of android applications as a learning media for mathematics in Indonesia is still below 50\%. The effect of performance expectancy, effort expectancy, and social influence on behavioral intention is illustrated by the regression equation $\hat{Y}_{1}=0.469 X_{1}+0.280 X_{2}+0.271 X_{3}-0.062$ while facilitating the regression equation $\hat{Y}_{2}=0.495 X_{4}+0.640 Y_{1}-0.379$ represents conditions and behavioral intention towards use behavior.
\end{abstract}

\section{Article History:}

Received: 10-10-2019

Revised : 29-11-2019

Accepted: 22-12-2019

Online : 30-12-2019

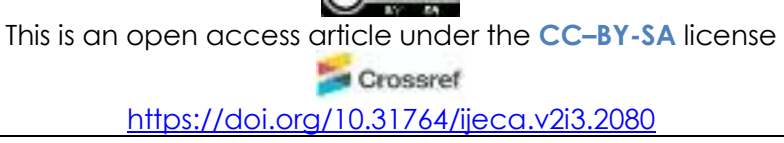

\section{A. INTRODUCTION}

At the beginning of its presence, the mobile phone only has the limited ability to make and receive calls and send and receive messages in the form of text known as Short Message Services (SMS) (Xu \& Wu, 2012),(Pan, 2018). Nowadays, mobile phone has been very developed so it has a wide range of capabilities such as for Internet access and also has operating system like computer so it is often called as smart mobile phone or better known as Smart phone terms (Shan, Wang, Feng, \& Li, 2012),(Blasco, 2016). Utilization of smart phone capability for purposes in several fields was developed with applications that are able to support the use. Including the use of smart phone usability is for learning media (Mehdipour \& Zerehkafi, 2013). One operating system that can be operated on a smart phone is the Android operating system (O'Bannon \& Thomas, 2015). Android is an operating system for mobile that is based on Linux and is open source.

The importance of using information technology such as this Android application began to be realized by the modern organization, especially in the era of globalization, where the company is required to be more competitive and competitive (Andrus \& Nieh, 2012),(Kang \& 
Cho, 2015). Therefore it becomes important to spur the utilization and use of such information technology. Researchers say that the decision to adopt an information technology system does exist in the hands of the manager, but the success of the use of such technology depends on the acceptance and use of each individual wearer, as in The Android application thing the success of application or its use is interrupted from the response of teachers and students as the main actors (Mandalina et al., 2019). So, the behavior of Android application users is formed from the attitude and perception of users; in this case, is the teacher and students of the application (Sharples \& Pea, 2015).

On such a request, it is necessary to do further searches on the application and acceptance of Android apps in educational institutions at the elementary, junior, and high school levels. One of the best methods of implementing this activity is using the Unified Theory of Acceptance and Use of Technology (UTAUT) method. The UTAUT model is a combination of eight previous methods that are more complete and well measured.

\section{B. METHODS}

This research is a descriptive quantitative study. Data is sourced from the results of a questionnaire deployment using a Google Form-based Black Box system. Questionnaires were compiled using the Likert 4 option with the number of questions or statements developed from the UTAUT model indicator. Respondents were netted from east, central, and West Indonesia regions. As for the relationship model, the fifth parameter UTAUT method as follows (Venkatesh, Thong, \& Xu, 2016), (Williams, Rana, \& Dwivedi, 2015).

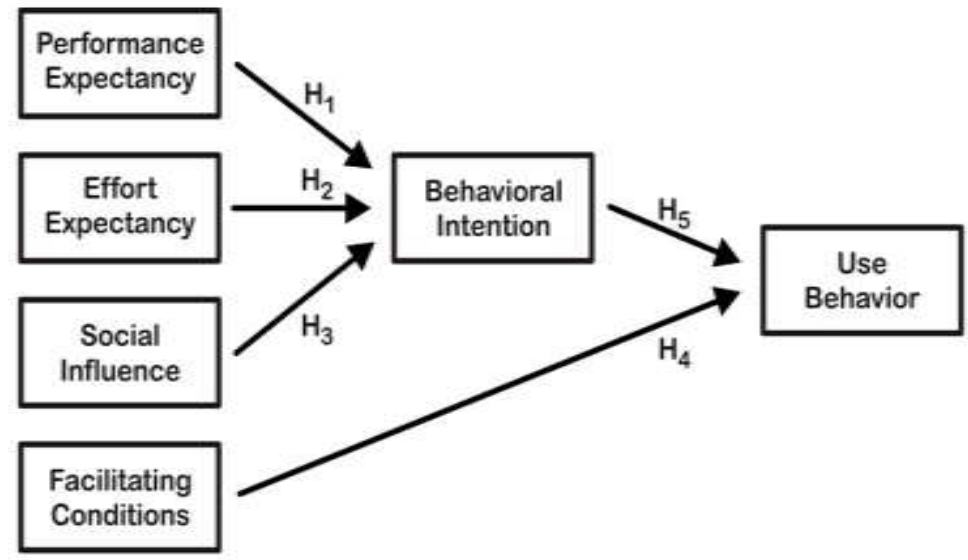

Figure 1. Model Research hypothesis Design

The research procedure is described in Figure 2 below.

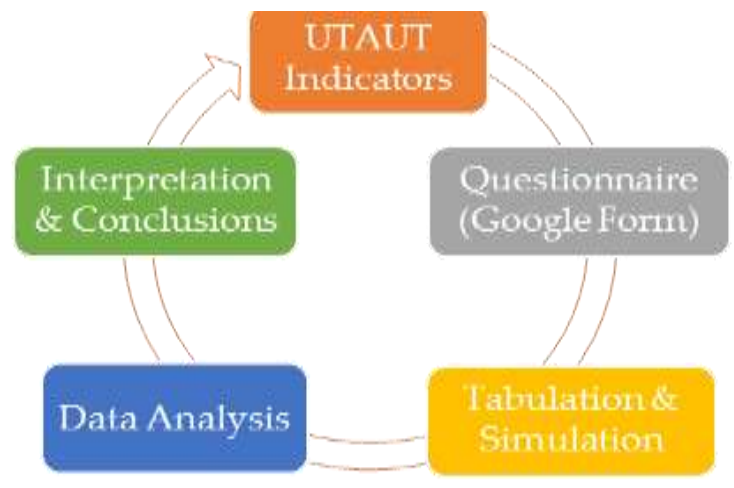

Figure 2. Research FlowChart

Based on Figure 2 above, the research phase is known to consist of 5 stages: 
1. Making a questionnaire based on the individual components of the UTAUT component consisting of performance expectancy, effort expectancy, social influence, behavioral intention, facilitating conditions, and user behavior.

2. Questionnaire distribution. At this stage, the team spread the questionnaire to users who are students and teachers online with the help of Google Form. The questionnaire is only given to junior and high school students as well as the teacher of subjects.

3. Tabulation and simulation data based on the UTAUT parameter.

4. Data analysis. At this stage, the research team conducted a data analysis consisting of descriptive tests and hypotheses testing.

5. Interpretation of data and conclusion. At this stage, the research team performs the interpretation of data from the results of data analysis, including the UTAUT parameter description and the hypothesis test results, finally drawing conclusions from the results of this research.

In this research, the data is found to be divided into two types, namely qualitative data in the form of the results of the Android application mapping, and quantitative data in the form of the results of the UTAUT parameter. Data is done by analyzing data using regression. Based on Figure 1, then the regression equation as follows.

$$
\begin{aligned}
& \hat{Y}_{1}=\alpha_{1} X_{1}+\alpha_{2} X_{2}+\alpha_{3} X_{3}+e \\
& \hat{Y}_{2}=\alpha_{4} X_{4}+\alpha_{5} Y_{1}+e
\end{aligned}
$$

The equation includes both behavioral intention and use behavior, as well as four free variables such as $\mathrm{X}_{1}$ (performance expectancy), $\mathrm{X}_{2}$ (effort expectancy), $\mathrm{X}_{3}$ (social influence), and $\mathrm{X}_{4}$ (facilitating conditions), while $\alpha$ is regression coefficient and $\boldsymbol{e}$ are error. So in this study, the team analyzed the data using multivariate analysis of variance (MANOVA) test. Next, the R (effect) value of each variable is specified in the category in Table 1 below.

Table 1. Correlation Value (R) and Its Category

\begin{tabular}{cl}
\hline Interval & \multicolumn{1}{c}{ Categories } \\
\hline $0.0 \leq r<0.2$ & Very low \\
\hline $0.2 \leq r<0.4$ & Low \\
\hline $0.4 \leq r<0.6$ & Standard (Strong enough) \\
\hline $0.6 \leq r<0.8$ & Strong \\
\hline $0.8 \leq r<1.0$ & Very strong \\
\hline
\end{tabular}

\section{RESULT AND DISCUSSION}

\subsection{Data Description}

From the results of the distribution of BlackBox based questionnaire using social media such as WhatsApp and Facebook obtained data collected as much as 43 respondents. It is known information that $20 \%$ of respondents have never applied Android apps in math learning. While 80\% has been implementing Android-based learning media such as: English-Indonesian dictionary, Frequency Analyzer, Advanced Spectrum, Lite Chromatic, Edmodo, Brainly, HOTS Learning, PhotoMath, CalculatorScientific, Maths Formulas for high school, Geogebra, Google Classroom, BSE, and MindMaping. Furthermore, of the 16 questionnaire items that we distribute are obtained data according to the following Table 2 .

Table 2. Utaut Questionnaire Average Score

\begin{tabular}{ccccccc}
\hline No & X1 & X2 & X3 & X4 & X5 & Y \\
\hline 1 & 3.0 & 3.0 & 3.0 & 3.0 & 3.0 & 3.0 \\
\hline 2 & 3.0 & 2.3 & 3.0 & 3.3 & 2.8 & 3.0 \\
\hline
\end{tabular}




\begin{tabular}{ccccccc}
\hline 3 & 4.0 & 4.0 & 4.3 & 4.0 & 4.1 & 4.0 \\
\hline 4 & 2.4 & 2.7 & 2.7 & 2.0 & 2.5 & 2.0 \\
\hline 5 & 3.0 & 3.0 & 3.0 & 3.0 & 3.0 & 3.0 \\
\hline 6 & 3.4 & 4.0 & 3.3 & 3.3 & 3.5 & 3.5 \\
\hline 7 & 3.2 & 3.0 & 3.0 & 3.0 & 3.1 & 3.0 \\
\hline 8 & 2.0 & 2.0 & 2.0 & 2.0 & 2.0 & 2.0 \\
\hline 9 & 3.4 & 3.0 & 3.7 & 3.3 & 3.4 & 3.5 \\
\hline 10 & 3.0 & 3.0 & 3.0 & 3.0 & 3.0 & 3.0 \\
\hline 11 & 2.8 & 2.3 & 3.3 & 2.0 & 2.8 & 2.5 \\
\hline 12 & 3.2 & 3.3 & 3.7 & 3.3 & 3.4 & 3.0 \\
\hline 13 & 4.0 & 4.0 & 4.3 & 4.0 & 4.1 & 4.0 \\
\hline 14 & 2.8 & 2.0 & 2.7 & 2.3 & 2.5 & 3.0 \\
\hline 15 & 3.4 & 2.7 & 3.7 & 3.0 & 3.3 & 4.0 \\
\hline 16 & 1.6 & 2.0 & 2.0 & 2.3 & 1.8 & 2.0 \\
\hline 17 & 3.2 & 3.0 & 3.0 & 2.0 & 3.1 & 3.0 \\
\hline 18 & 4.0 & 4.0 & 3.3 & 3.3 & 3.8 & 4.0 \\
\hline 19 & 3.8 & 3.0 & 3.7 & 3.0 & 3.5 & 3.5 \\
\hline 20 & 4.0 & 3.3 & 2.0 & 3.7 & 3.3 & 4.0 \\
\hline 21 & 2.6 & 2.3 & 1.7 & 2.3 & 2.3 & 3.0 \\
\hline 22 & 3.8 & 3.3 & 3.0 & 3.0 & 3.5 & 4.0 \\
\hline 23 & 3.0 & 3.0 & 3.3 & 3.0 & 3.1 & 3.0 \\
\hline 24 & 2.2 & 2.7 & 2.0 & 3.0 & 2.3 & 1.0 \\
\hline 25 & 4.0 & 3.0 & 3.0 & 2.7 & 3.5 & 3.5 \\
\hline 26 & 4.0 & 4.0 & 4.0 & 4.0 & 4.0 & 4.0 \\
\hline 27 & 3.0 & 2.7 & 3.0 & 3.7 & 2.9 & 3.5 \\
\hline 28 & 3.0 & 2.7 & 3.0 & 2.7 & 2.9 & 2.5 \\
\hline 29 & 3.8 & 3.7 & 2.3 & 2.3 & 3.4 & 3.0 \\
\hline 30 & 3.0 & 2.7 & 3.0 & 3.7 & 2.9 & 3.5 \\
\hline 31 & 2.8 & 2.7 & 2.0 & 1.7 & 2.5 & 1.5 \\
\hline 32 & 3.0 & 3.0 & 3.3 & 3.3 & 3.1 & 3.5 \\
\hline 33 & 2.0 & 2.0 & 1.7 & 3.3 & 1.9 & 2.5 \\
\hline 34 & 4.0 & 4.0 & 4.3 & 4.0 & 4.1 & 4.0 \\
\hline 35 & 3.2 & 3.3 & 4.0 & 3.7 & 3.5 & 2.5 \\
\hline 36 & 3.2 & 3.0 & 1.7 & 3.3 & 2.7 & 3.5 \\
\hline 37 & 3.0 & 3.0 & 3.0 & 3.0 & 3.0 & 3.0 \\
\hline 38 & 3.0 & 3.0 & 3.0 & 2.0 & 3.0 & 1.5 \\
\hline 39 & 2.8 & 3.0 & 3.7 & 4.0 & 3.1 & 4.0 \\
\hline 40 & 2.6 & 2.5 & 2.7 & 3.0 & 2.6 & 3.0 \\
\hline 42 & 4.0 & 4.0 & 2.0 & 4.0 & 3.5 & 4.0 \\
\hline 43 & 2.4 & 2.7 & 2.3 & 3.0 & 2.6 & 2.5 \\
\hline & & & & & & \\
\hline 13 & 2.7 & 2.6 & 2.5 \\
\hline 10
\end{tabular}




\subsection{Data Analysis}

\section{Effect of X1, X2, X3 and X5 to $Y$}

At this stage, the team uses the SPSS help in determining regression equations according to Equation 1 and Equation 2. Based on Figure 1 obtained SPSS output obtained results as follows.

Table 3. Variable Correlation Value X1, X2, X3, and X5

Correlations

\begin{tabular}{|lc|r|r|r|r|}
\hline & & \multicolumn{1}{c|}{ X5 } & \multicolumn{1}{c|}{ X1 } & \multicolumn{1}{c|}{ X2 } & \multicolumn{1}{c|}{ X3 } \\
\hline Pearson Correlation & X5 & 1.000 & .929 & .895 & .752 \\
& X1 & .929 & 1.000 & .838 & .502 \\
& X2 & .895 & .838 & 1.000 & .503 \\
& X3 & .752 & .502 & .503 & 1.000 \\
\hline Sig. (1-tailed) & X5 &. & .000 & .000 & .000 \\
& X1 & .000 &. & .000 & .000 \\
& X2 & .000 & .000 &. & .000 \\
& X3 & .000 & .000 & .000 & \\
\hline $\mathrm{N}$ & $\mathrm{X} 5$ & 43 & 43 & 43 & 43 \\
& $\mathrm{X} 1$ & 43 & 43 & 43 & 43 \\
& $\mathrm{X} 2$ & 43 & 43 & 43 & 43 \\
& $\mathrm{X} 3$ & 43 & 43 & 43 & 43 \\
\hline
\end{tabular}

Based on the output in table 3 above it appears that the significant (sig.) Value of all variables under $0.05(5 \%)$, this means there is an influence between variables. In addition, it can be known also the level of influence of each variable according to the value of the correlation given:

Table 4. Correlation Value (R) and Correlation Level

\begin{tabular}{cl}
\hline Variabel & \multicolumn{1}{c}{ X5 } \\
\hline $\mathrm{X} 1$ & 0.929 (Very Strong) \\
\hline $\mathrm{X} 2$ & 0.895 (Very Strong) \\
\hline $\mathrm{X} 3$ & 0.752 (Strong) \\
\hline
\end{tabular}

Then, value of regression and $\mathrm{R}^{2}$ based on Table 5 below:

Table 5. Model Summary ${ }^{B}$

\begin{tabular}{|c|c|c|c|c|}
\hline Model & $\mathrm{R}$ & R Square & $\begin{array}{l}\text { Adjusted R } \\
\text { Square }\end{array}$ & $\begin{array}{l}\text { Durbin- } \\
\text { Watson }\end{array}$ \\
\hline 1 & $.999 a$ & .998 & .998 & 1.854 \\
\hline
\end{tabular}

According to Table 5 above it appears that a regression value of 0.99 which means "very strong". This is evidenced by the $\mathrm{R}^{2}$ value that says that a $99.8 \%$ variable $\mathrm{X} 1, \mathrm{X} 2$, and $\mathrm{X} 3$ affects the $\mathrm{X} 5$ variables.

Next, we can make regression equations according to Table 6 below: 
Table 6. Coefficients Value

\begin{tabular}{|c|c|c|c|c|c|}
\hline \multirow[b]{2}{*}{ Model } & \multicolumn{2}{|c|}{$\begin{array}{l}\text { Unstandardized } \\
\text { Coefficients }\end{array}$} & \multirow{2}{*}{$\begin{array}{c}\begin{array}{c}\text { Standardize } \\
\mathrm{d} \\
\text { Coefficients }\end{array} \\
\text { Beta } \\
\end{array}$} & \multirow[b]{2}{*}{$\mathrm{t}$} & \multirow[b]{2}{*}{ Sig. } \\
\hline & B & $\begin{array}{l}\text { Std. } \\
\text { Error }\end{array}$ & & & \\
\hline $1 \begin{array}{ll}\text { (Cons } \\
\text { tant) }\end{array}$ & -.062 & .024 & & -2.574 & .014 \\
\hline $\mathrm{X} 1$ & .469 & .013 & .508 & 35.765 & .000 \\
\hline $\mathrm{X} 2$ & .280 & .014 & .294 & 20.678 & .000 \\
\hline X3 & .271 & .007 & .350 & 39.053 & .000 \\
\hline
\end{tabular}

a. Dependent Variable: X5

Based on Table 6 above obtained regression equations such as:

$$
\hat{Y}_{1}=0.469 X_{1}+0.280 X_{2}+0.271 X_{3}-0.062
$$

\section{Effect of $X 4$ and $X 5$ to $Y$}

Form data analysis we can know variable correlation values according on Table 7 below:

Table 7. Variable Correlation Value X4, X5, and Y

\begin{tabular}{|ll|r|r|r|}
\hline & & \multicolumn{1}{c|}{$\mathrm{Y}$} & \multicolumn{1}{c|}{ X4 } & \multicolumn{1}{c|}{ X5 } \\
\hline Pearson & $\mathrm{Y}$ & 1.000 & .696 & .718 \\
Correlation & $\mathrm{X} 4$ & .696 & 1.000 & .592 \\
& $\mathrm{X} 5$ & .718 & .592 & 1.000 \\
\hline Sig. (1-tailed) & $\mathrm{Y}$ &. & .000 & .000 \\
& $\mathrm{X} 4$ & .000 &. & .000 \\
& $\mathrm{X} 5$ & .000 & .000 & \\
\hline $\mathrm{N}$ & $\mathrm{Y}$ & 43 & 43 & 43 \\
& $\mathrm{X} 4$ & 43 & 43 & 43 \\
& $\mathrm{X} 5$ & 43 & 43 & 43 \\
\hline
\end{tabular}

Based on the output in table 7 above it appears that the significant (sig.) Value of all variables under $0.05(5 \%)$, this means there is an influence between variables. In addition, it can be known also the level of influence of each variable according to the value of the correlation given:

Table 8. R Value and Correlation Level

\begin{tabular}{cc}
\hline Variable & $\mathbf{Y}$ \\
\hline $\mathrm{X} 4$ & 0.696 (Strong) \\
\hline $\mathrm{X} 5$ & 0.718 (Strong) \\
\hline
\end{tabular}

Next, we can find out the Regression and R2 values based on Table 9 below.

Table 9. Model Summary ${ }^{\mathrm{B}}$

\begin{tabular}{|l|c|r|r|c|}
\hline & & & Adjusted R \\
Model & $\mathrm{R}$ & R Square & $\begin{array}{c}\text { Std. Error of the } \\
\text { Estimate }\end{array}$ \\
\hline 1 & $.793^{\mathrm{a}}$ & .628 & .610 & .47991 \\
\hline
\end{tabular}

a. Predictors: (Constant), X5, X4

b. Dependent Variable: Y 
According to Table 9 above it appears that the regression value is 0.793 which means "strong". It is evidenced from the $\mathrm{R} 2$ value of $62.8 \%$ variable $\mathrm{X} 4$ and $\mathrm{X} 5$ affects the variable $\mathrm{Y}$. Then, we specify the corresponding regression equation output in Table 10 below.

Table 10. Coefficients Value

\begin{tabular}{|c|c|c|c|c|c|}
\hline \multirow[b]{2}{*}{ Model } & \multicolumn{2}{|c|}{$\begin{array}{c}\text { Unstandardized } \\
\text { Coefficients }\end{array}$} & \multirow{2}{*}{\begin{tabular}{|c}
$\begin{array}{c}\text { Standardize } \\
\mathrm{d} \\
\text { Coefficients }\end{array}$ \\
Beta \\
\end{tabular}} & \multirow[b]{2}{*}{$\mathrm{t}$} & \multirow[b]{2}{*}{ Sig. } \\
\hline & B & Std. Error & & & \\
\hline $1 \quad$ (Constant) & -.379 & .428 & & -.886 & .381 \\
\hline $\mathrm{X} 4$ & .495 & .142 & .417 & 3.484 & .001 \\
\hline X5 & .640 & .162 & .472 & 3.944 & .000 \\
\hline
\end{tabular}

a. Dependent Variable: $Y$

Based on Table 10 above obtained regression equations such as:

$$
\hat{Y}_{2}=0.495 X_{4}+0.640 Y_{1}-0.379
$$

From the results of SPSS-assisted data analysis, it is known that all hypotheses are received with the value of SIG. Sebsar 0.000 Both the first hypothesis and the fifth hypothesis. This is reinforced by the average correlation value, including the "strong" category. Then if viewed from the $\hat{Y}_{1}=0.469 X_{1}+0.280 X_{2}+0.271 X_{3}-0.062$ regression equation, this gives the meaning that each given a treatment of 1 of each variable (X1, X2, and X3), it will happen an influence or hike to the Y1 variable by 0958 . Similarly, the second regression of the $\hat{Y}_{2}=0.495 X_{4}+0.640 Y_{1}-0.379$, if given a treat of 1 of each variable (X4 and X5), there will be an influence or increment to the Y2 variable of 0756 .

Another thing that is recorded during data retrieval is at the level of elementary and junior school; the application of Android media averages still below 10\%, while at the average high school level is approaching the number $50 \%$. Then the implementation of this Android media is the highest average used by teachers at a young age (26-45 years old).

\section{CONCLUSION AND SUGGESTIONS}

Android-based learning is indispensable in the present considering the facilities and circumstances that the students have in most do not utilize Smartphones as a learning medium, but for a little need to give benefits. However, based on the logging in the field, learning by applying Android applications as a learning tool is still below 50\%. The need for more socialization of the academy at the government level or higher education institutions to teachers in schools in the development and utilization of Android-based learning media so that the negative effect of use Smartphones can be addressed with more useful things in addition to the demands of teachers to master information and communication technologies.

\section{ACKNOWLEDGMENT}

The research team would like to thank the Research Institute of the University of Muhammadiyah Mataram, as well as the teachers and students who have filled out the questionnaire that we have distributed so that the research is going well 


\section{REFERENCES}

Andrus, J., \& Nieh, J. (2012). Teaching operating systems using android. SIGCSE'12 - Proceedings of the 43rd ACM Technical Symposium on Computer Science Education, 613-618. https://doi.org/10.1145/2157136.2157312

Blasco, D. (2016). What are the Alternative Functions and Benefits of Cell Phones for Students? International Journal on Integrating Technology in Education, 5(4), 01-12. https://doi.org/10.5121/ijite.2016.540

Kang, H., \& Cho, J. (2015). Case study on efficient Android programming education using multi Android development tools. Indian Journal of Science and Technology, 8(19). https://doi.org/10.17485/ijst/2015/v8i19/75984

Mandalina, V., Syaharuddin, Firdaus, M., Abdillah, Pramita, D., \& Negara, H. R. P. (2019). Math mobile learning app as an interactive multimedia learning mathematics. International Journal of Scientific and Technology Research, 8(10), 2548-2550.

Mehdipour, Y., \& Zerehkafi, H. (2013). Mobile Learning for Education: Benefits and Challenges. International Journal of Computational ..., 3(6), 93-101 (251-259).

O'Bannon, B. W., \& Thomas, K. M. (2015). Mobile phones in the classroom: Preservice teachers answer the call. Computers and Education, 85, 110-122. https://doi.org/10.1016/j.compedu.2015.02.010

Pan, X. (2018). Interactive Design of Mobile Phone Interface. Progress in Human Computer Interaction, 1(1). https://doi.org/10.18063/phci.v1i1.553

Shan, W., Wang, M., Feng, J., \& Li, Z. (2012). A study on educational administration inquire system based on mobile device. CSAE 2012 - Proceedings, 2012 IEEE International Conference on Computer Science and Automation Engineering, 3, 392-395. https://doi.org/10.1109/CSAE.2012.6272979

Sharples, M., \& Pea, R. (2015). Mobile learning and mathematics: foundations, design, and case studies. In The Cambridge Handbook of the Learning Sciences (pp. 501-521). https://doi.org/10.1017/CB09781139519526.030

Venkatesh, V., Thong, J., \& Xu, X. (2016). The unified theory of acceptance and use of technology (UTAUT). Journal of the Association for Imformation Systems, 17(5), 328-376.

Williams, M. D., Rana, N. P., \& Dwivedi, Y. K. (2015). The unified theory of acceptance and use of technology (UTAUT): A literature review. Journal of Enterprise Information Management, Vol. 28, pp. 443-448. https://doi.org/10.1108/JEIM-09-2014-0088

$\mathrm{Xu}, \mathrm{L}$. J., \& Wu, K. J. (2012). The application and implementation of SMS platform in mobile digital campus. International Journal of Digital Content Technology and Its Applications, 6(19), 98-105. https://doi.org/10.4156/jdcta.vol6.issue19.13 